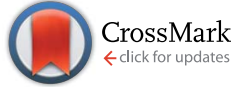

Cite this: RSC Adv., 2015, 5, 38977

Received 11th January 2015 Accepted 23rd April 2015

DOI: $10.1039 / \mathrm{c} 5 \mathrm{ra00600g}$

www.rsc.org/advances

\section{Synthesis of ammonia directly from wet nitrogen using a redox stable $\mathrm{La}_{0.75} \mathrm{Sr}_{0.25} \mathrm{Cr}_{0.5} \mathrm{Fe}_{0.5} \mathrm{O}_{3-\delta^{-}}$ $\mathrm{Ce}_{0.8} \mathrm{Gd}_{0.18} \mathrm{Ca}_{0.02} \mathrm{O}_{2-\delta}$ composite cathode}

\begin{abstract}
Ibrahim A. Amar, ${ }^{a}$ Rong Lan ${ }^{a}$ and Shanwen Tao*ab
Ammonia was directly synthesised from wet nitrogen at an intermediate temperature $\left(375-425^{\circ} \mathrm{C}\right)$ based on the oxygen-ion conduction of the $\mathrm{Ce}_{0.8} \mathrm{Gd}_{0.18} \mathrm{Ca}_{0.02} \mathrm{O}_{2-\delta}-\left((\mathrm{Li} / \mathrm{Na} / \mathrm{K})_{2} \mathrm{CO}_{3}\right)$ composite electrolyte. $\mathrm{A}$ redox stable perovskite-based catalyst, $\mathrm{La}_{0.75} \mathrm{Sr}_{0.25} \mathrm{Cr}_{0.5} \mathrm{Fe}_{0.5} \mathrm{O}_{3-\delta}$ (LSCrF), was synthesised via a combined EDTA-citrate complexing sol-gel process to be used as a component of the $\mathrm{La}_{0.75} \mathrm{Sr}_{0.25} \mathrm{Cr}_{0.5} \mathrm{Fe}_{0.5} \mathrm{O}_{3-\delta^{-}}$ $\mathrm{Ce}_{0.8} \mathrm{Gd}_{0.18} \mathrm{Ca}_{0.02} \mathrm{O}_{2-\delta}$ composite cathode for ammonia synthesis. Ammonia formation was studied at 375,400 and $425{ }^{\circ} \mathrm{C}$ and a maximum ammonia formation rate of $4.0 \times 10^{-10} \mathrm{~mol} \mathrm{~s}^{-1} \mathrm{~cm}^{-2}$ with corresponding Faradaic efficiency of $3.87 \%$ was observed at $375^{\circ} \mathrm{C}$ when the applied voltage was $1.4 \mathrm{~V}$. This is much higher than $7.0 \times 10^{-11} \mathrm{~mol} \mathrm{~s}^{-1} \mathrm{~cm}^{-2}$ at $1.4 \mathrm{~V}$ and $400{ }^{\circ} \mathrm{C}$ when $\mathrm{Cr}$-free $\mathrm{Sr}$-doped $\mathrm{LaFeO}_{3-\delta}, \mathrm{La}_{0.6} \mathrm{Sr}_{0.4} \mathrm{FeO}_{3-\delta}$ was used as the catalyst for the electrochemical synthesis of ammonia, indicating LSCrF is potentially a better catalyst. Ammonia was successfully synthesised using a redox stable cathode with higher formation rates at reduced temperature. Introduction of $\mathrm{Cr}^{3+}$ ions at the Bsite of doped $\mathrm{LaFeO}_{3}$ improves both the chemical stability and catalytic activity for ammonia synthesis.
\end{abstract}

\section{Introduction}

Ammonia is the second most produced chemical in large quantities in the world. It is not only an end product but also an important intermediate in the manufacture of many chemicals including; urea, nitric acid, ammonium nitrate, ammonium sulphate and ammonium phosphate. ${ }^{1}$ In 2011 , approximately 136 million metric tons of ammonia was produced of which $\sim 80 \%$ was consumed by the fertiliser industry. ${ }^{1,2}$

Currently, ammonia is produced on a large-scale via the Haber-Bosch process which was developed in the early 1900s. This process suffers from many drawbacks including; the low ammonia conversion (10-15\%), high energy consumption, operation at high temperature $\left(\sim 500{ }^{\circ} \mathrm{C}\right)$ and high pressure (150-300 bar) and severe environmental pollution $\left(\mathrm{CO}_{2}\right.$ emission). ${ }^{1}$ Therefore, to avoid the Haber processes thermodynamic limitations (limited conversion) and to reduce the $\mathrm{CO}_{2}$ emission, alternative ammonia synthesis approaches have been proposed. In 1996, Panagos et al. ${ }^{3}$ proposed a model process using a solid state proton conductor to overcome the thermodynamic constraints of the traditional ammonia synthesis process. In 1998, Marnellos and Stoukides ${ }^{4}$ confirmed the first experimental ammonia synthesis from its constituents $\left(\mathrm{H}_{2}\right.$ and $\mathrm{N}_{2}$ ) at atmospheric pressure using an electrochemical cell

${ }^{a}$ Department of Chemical \& Process Engineering, University of Strathclyde, Glasgow G1 1XJ, UK. E-mail: shanwen.tao@strath.ac.uk; Fax: +44 (o) 141548 2539; Tel: +44 (0) 1415482361

${ }^{b}$ School of Engineering, University of Warwick, Coventry CV4 7AL, UK based on the proton-conducting electrolyte $\mathrm{SrCe}_{0.95} \mathrm{Yb}_{0.05} \mathrm{O}_{3-\delta}$ $(\mathrm{SCYb}){ }^{4}$

In the literature, several solid state proton conductors have been used as electrolytes for synthesising ammonia electrochemically. ${ }^{5-10}$ In these mentioned reports, pure $\mathrm{H}_{2}$ was used as source of the required protons $\left(\mathrm{H}^{+}\right)$for ammonia synthesis. However, there are some problems associated with using $\mathrm{H}_{2}$ as one of the precursors including; the production, purification, storage and transportation of hydrogen. ${ }^{\mathbf{1 1 , 1 2}}$ On other hand, water can be used as an ideal proton source. In 2009, Skodra and Stoukides ${ }^{\mathbf{1 3}}$ reported the synthesis of ammonia for first time directly from $\mathrm{H}_{2} \mathrm{O}$ and $\mathrm{N}_{2}$ without the need for hydrogen production stage. In that study, either solid oxide protonic or oxygen ion conductors was used as an electrolyte and Ru-based catalyst was used as a working electrode (cathode). Ammonia was produced under atmospheric pressure with a maximum formation rate of $\sim 4 \times 10^{-13} \mathrm{~mol} \mathrm{~s}^{-1} \mathrm{~cm}^{-2}$ at $650{ }^{\circ} \mathrm{C}$ at $2 \mathrm{~V}$. Recently, ammonia has been synthesised directly from $\mathrm{H}_{2} \mathrm{O}$ and $\mathrm{N}_{2}$ using an electrolytic cell based on $\mathrm{CoFe}_{2} \mathrm{O}_{4}-\mathrm{CGDC}$ composite as a cathode and doped ceria-carbonate composite as $\mathrm{O}^{2-}$ conducting electrolyte. ${ }^{14}$ In that study, the ammonia production rate of $6.5 \times 10^{-11} \mathrm{~mol} \mathrm{~s}^{-1} \mathrm{~cm}^{-2}$ was obtained at $400{ }^{\circ} \mathrm{C}$ and $1.6 \mathrm{~V}$.

The principle electrochemical synthesis of ammonia from water and $\mathrm{N}_{2}$ based on oxide-ion $\left(\mathrm{O}^{2-}\right)$ conducting electrolytes can be written as follows, ${ }^{13}$

At the cathode,

$$
3 \mathrm{H}_{2} \mathrm{O}+\mathrm{N}_{2}+6 \mathrm{e}^{-} \rightarrow 3 \mathrm{O}^{2-}+2 \mathrm{NH}_{3}
$$


At the anode, the transported oxygen ions through the electrolyte will combine to form oxygen gas;

$$
3 \mathrm{O}^{2-} \rightarrow \frac{3}{2} \mathrm{O}_{2}+6 \mathrm{e}^{-}
$$

The overall reaction will be;

$$
3 \mathrm{H}_{2} \mathrm{O}+\mathrm{N}_{2} \rightarrow 2 \mathrm{NH}_{3}+\frac{3}{2} \mathrm{O}_{2}
$$

Under the circumstance, if wet nitrogen is fed in the cathode in a two chamber cell, when a dc voltage is applied to the cell, ammonia will be produced at the cathode, oxygen at the anode. However, water splitting reaction is another completing reaction at the cathode,

$$
\mathrm{H}_{2} \mathrm{O}+2 \mathrm{e}^{-} \rightarrow \mathrm{H}_{2}+\mathrm{O}^{2-}
$$

The produced $\mathrm{O}^{2-}$ ions will transport to the anode, releasing oxygen according to reaction (2). The overall reaction for water splitting reaction is,

$$
2 \mathrm{H}_{2} \mathrm{O} \rightarrow 2 \mathrm{H}_{2}+\mathrm{O}_{2}
$$

Therefore the ammonia synthesis and water splitting processes are competing with each other. Both ammonia and hydrogen can be produced at the cathode, depending on the catalytic activity of the cathode catalysts. Very important, the produced hydrogen at the cathode may further reaction with the catalysts, causing degradation of catalytic activity. Therefore an ideal ammonia synthesis catalyst should be redox stable which can sustain the highly reducing atmosphere in the presence of hydrogen at high temperatures.

The perovskite-based oxides are of interest owing to their ease of synthesis, low manufacture cost, high thermal stability and good catalytic activity. ${ }^{15}$ These oxides have been used as electrodes in many applications such as solid oxide fuel cells (SOFCs), ${ }^{16-19}$ solid oxide steam electrolysis cells (SOECs) ${ }^{20-22}$ and electrochemical synthesis of ammonia. ${ }^{23-26}$ Tao and Irvine investigated the redox stability and catalytic properties of $\mathrm{La}_{0.75} \mathrm{Sr}_{0.25} \mathrm{Cr}_{0.5} \mathrm{Fe}_{0.5} \mathrm{O}_{3-\delta}$ (LSCrF). ${ }^{27}$ In that study, it was found out that LSCrF exhibited excellent catalytic activity for methanereforming. LSCrF is a redox stable oxide with electronic conductivity of approximately 14.3 in air and $0.21 \mathrm{~S} \mathrm{~cm}^{-1}$ in $5 \%$ $\mathrm{H}_{2}$ at $900{ }^{\circ} \mathrm{C}^{27}$ On the other hand, the industrial ammonia synthesis catalysts are mainly Fe-based composite. To use a Fecontaining perovskite as cathode catalysts for electrochemical synthesis of ammonia will be a good approach. Fe-containing perovskite oxides $\mathrm{SmFe}_{0.7} \mathrm{Cu}_{0.1} \mathrm{Ni}_{0.2} \mathrm{O}_{3-\delta}(\mathrm{SFCN}), \mathrm{SmBaCuFeO}_{5+\delta}$ (SBCF) have been reported as cathode for electrochemical synthesis of ammonia from $\mathrm{N}_{2}$ and $\mathrm{H}_{2}$ based on electrochemical cells using Nafion as the electrolyte..$^{5,29,30}$ The highest observed ammonia formation rate was $1.13 \times 10^{-8} \mathrm{~mol} \mathrm{~s}^{-1} \mathrm{~cm}^{-2}$ when SFCN was used as the cathode with an operating temperature of $80{ }^{\circ} \mathrm{C} .{ }^{29}$ For high temperature cells, perovskite oxide $\mathrm{Ba}_{0.5} \mathrm{Sr}_{0.5^{-}}$ $\mathrm{Co}_{0.8} \mathrm{Fe}_{0.2} \mathrm{O}_{3-\delta}$ combined with $\mathrm{Ag}-\mathrm{Pd}$ film was used as cathode for electrochemical synthesis of ammonia from $\mathrm{N}_{2}$ and $\mathrm{H}_{2}$ and an ammonia formation rate of $4.1 \times 10^{-9} \mathrm{~mol} \mathrm{~s}^{-1} \mathrm{~cm}^{-2}$ was observed at $530{ }^{\circ} \mathrm{C}$ for a cell based on $\mathrm{BaCe}_{0.85} \mathrm{Y}_{0.15} \mathrm{O}_{3-\delta}$ (BCY15) electrolyte. ${ }^{23} \mathrm{We}$ also investigated the use of perovskite oxide $\mathrm{La}_{0.6} \mathrm{Sr}_{0.4} \mathrm{Fe}_{0.8} \mathrm{Cu}_{0.2} \mathrm{O}_{3-\delta}$ as the cathode and an ammonia formation rate of $5.39 \times 10^{-9} \mathrm{~mol} \mathrm{~s}^{-1} \mathrm{~cm}^{-2}$ at $450{ }^{\circ} \mathrm{C}$ was observed..$^{24} \mathrm{In}$ a previous study, we reported that a maximum ammonia formation rate of $7.0 \times 10^{-11} \mathrm{~mol} \mathrm{~s}{ }^{-1} \mathrm{~cm}^{-2}$ was observed at $400{ }^{\circ} \mathrm{C}$ and $1.4 \mathrm{~V}$ when $\mathrm{La}_{0.6} \mathrm{Sr}_{0.4} \mathrm{FeO}_{3-\delta}-\mathrm{Ce}_{0.8} \mathrm{Gd}_{0.18} \mathrm{Ca}_{0.02} \mathrm{O}_{2-\delta}$ composite was used as the cathode. ${ }^{28}$ To the best of our knowledge, there is no report on the electrochemical synthesis of ammonia using LSCrF as the catalyst. Here, for the first time, we report the synthesis of ammonia directly wet $\mathrm{N}_{2}$ in an electrolytic cell using redox stable $\mathrm{La}_{0.75} \mathrm{Sr}_{0.25} \mathrm{Cr}_{0.5} \mathrm{Fe}_{0.5} \mathrm{O}_{3-\delta^{-}}$ $\mathrm{Ce}_{0.8} \mathrm{Gd}_{0.18} \mathrm{Ca}_{0.02} \mathrm{O}_{2-\delta}$ (LSCrF-CGDC) composite as the cathode. $\mathrm{Ce}_{0.8} \mathrm{Gd}_{0.18} \mathrm{Ca}_{0.02} \mathrm{O}_{2-\delta}-\left((\mathrm{Li} / \mathrm{Na} / \mathrm{K})_{2} \mathrm{CO}_{3}\right)$ composite was used as electrolyte using its oxygen-ion $\left(\mathrm{O}^{2-}\right)$ conduction.

\section{Experimental}

\subsection{Materials synthesis}

$\mathrm{La}_{0.75} \mathrm{Sr}_{0.25} \mathrm{Cr}_{0.5} \mathrm{Fe}_{0.5} \mathrm{O}_{3-\delta}$ (LSCrF) catalyst was synthesised via a combined EDTA-citrate complexing sol-gel process. Lanthanum oxide $\left(\mathrm{La}_{2} \mathrm{O}_{3}\right.$, Alfa Aesar, 99\%), strontium nitrate $\left(\mathrm{Sr}\left(\mathrm{NO}_{3}\right)_{2}\right.$, Alfa Aesar, 99\%) and chromium nitrate nonahydrate $\left(\mathrm{Cr}\left(\mathrm{NO}_{3}\right)_{3} \cdot 9 \mathrm{H}_{2} \mathrm{O}\right.$, Sigma Aldrich, 99\%) iron nitrate nonahydrate $\left(\mathrm{Fe}\left(\mathrm{NO}_{3}\right)_{3} \cdot 9 \mathrm{H}_{2} \mathrm{O}\right.$, Alfa Aesar, 98\%) were used as starting materials. $\mathrm{La}_{2} \mathrm{O}_{3}$ was dissolved in diluted nitric acid to form lanthanum nitrate. Calculated amounts of $\operatorname{Sr}\left(\mathrm{NO}_{3}\right)_{2}, \mathrm{Cr}\left(\mathrm{NO}_{3}\right)_{3}$ $\cdot 9 \mathrm{H}_{2} \mathrm{O}$ and $\mathrm{Fe}\left(\mathrm{NO}_{3}\right)_{3} \cdot 9 \mathrm{H}_{2} \mathrm{O}$ were dissolved in deionised water and then added to the lanthanum nitrate solution. Citric acid and EDTA (ethylenediaminetetraacetic acid) were then added as complexing agents with molar ratio of citric acid : EDTA : metal cations of $1.5: 1: 1 . \mathrm{NH}_{3} \cdot \mathrm{H}_{2} \mathrm{O}$ was added to the mixed solution to adjust the $\mathrm{pH}$ value to around 6 . Under heating and stirring, the solution was evaporated on a hot-plate, and then gradually changed into a black sticky gel before complete drying. The asprepared powder was ground and subsequently calcined in air at $1200{ }^{\circ} \mathrm{C}$ for $2 \mathrm{~h}$ with heating/cooling rates of $5{ }^{\circ} \mathrm{C} \mathrm{min}^{-1}$ to obtain a pure phase of LSCrF catalyst without any carbon residue.

$\mathrm{Sm}_{0.5} \mathrm{Sr}_{0.5} \mathrm{CoO}_{3-\delta}$ (SSCo) catalyst and $\mathrm{Gd}$ and $\mathrm{Ca}$ co-doped ceria $\mathrm{Ce}_{0.8} \mathrm{Gd}_{0.18} \mathrm{Ca}_{0.02} \mathrm{O}_{2-\delta}$ (CGDC) powders were also synthesised via a combined EDTA-citrate complexing sol-gel process as described elsewhere. The composite electrolyte was prepared by mixing CGDC and ternary carbonate $((\mathrm{Li} / \mathrm{Na} /$ $\mathrm{K})_{2} \mathrm{CO}_{3}$ ) in weight ratio of $70: 30$ as described elsewhere. ${ }^{14}$

\subsection{Materials characterisation}

$\mathrm{X}$-ray diffraction (XRD) data were collected at room temperature using a Panalytical X'Pert Pro diffractometer with Ni-filtered $\mathrm{CuK} \alpha$ radiation $(\lambda=1.5405 \AA)$, using $40 \mathrm{kV}$ and $40 \mathrm{~mA}$, fitted with a X'Celerator detector. Absolute scans were recorded in the $2 \theta$ range $5-100^{\circ}$, with a step size of $0.0167^{\circ}$.

The microstructures of the prepared catalyst and the crosssectional area of the single cell were examined using a Hitachi SU6600 Scanning Electron Microscope (SEM). 
Thermogravimetry and differential scanning calorimetry (TGA/DSC) analyses were performed using a Stanton Redcroft STA/TGH series STA 1500 , operating through a Rheometric Scientific system interface controlled by the software RSI Orchestrator. The thermal behaviour of the perovskite based cathode (LSCrF) was investigated in $\mathrm{N}_{2}$ atmosphere from room temperature to $500{ }^{\circ} \mathrm{C}$ with a heating/cooling rate of $10{ }^{\circ} \mathrm{C} \mathrm{min}^{-1}$.

\subsection{Fabrication of the single cell for ammonia synthesis}

A tri-layer single cell was fabricated by a cost-effective, one-step, dry-pressing method. The composite anode was prepared by mixing in a mortar SSCo, CGDC and a pore former (starch), with weight ratio of $70: 30: 15$. The composite electrolyte consists of $\mathrm{CGDC} /(\mathrm{Li} / \mathrm{Na} / \mathrm{K})_{2} \mathrm{CO}_{3}(70: 30 \mathrm{wt} \%)$. The composite cathode was prepared by mixing in a mortar LSCrF, CGDC and starch, with weight ratio of $70: 30: 15$. The composite anode, composite electrolyte and composite cathode were fed into the die, layer by layer, with the aid of a sieve to ensure uniform powder distribution, and then uniaxially pressed at pressure of $121 \mathrm{MPa}$. This freshly made green pellet was sintered in air at $700{ }^{\circ} \mathrm{C}$ for $2 \mathrm{~h}$, at a rate of $2^{\circ} \mathrm{C} \mathrm{min}^{-1}$ on heating/cooling. The active surface area of the cathode was $0.785 \mathrm{~cm}^{2}$. Silver paste was painted in a grid pattern on each electrode surface of the cell, as a current collector. Ag wires were used as output terminals for both electrodes.

\subsection{Ammonia synthesis}

The fabricated single cells for ammonia synthesis were sealed into a self-designed double-chamber reactor, using ceramic paste (Aremco, Ceramabond 552). The electrolytic cell for ammonia was constructed as follows: air, SSCo-CGDC|CGDCcarbonate|LSCrF-CGDC, $3 \% \mathrm{H}_{2} \mathrm{O}-\mathrm{N}_{2}$. The cathode chamber was fed with $3 \% \mathrm{H}_{2} \mathrm{O}-\mathrm{N}_{2}$ (wet $\left.\mathrm{N}_{2}\right)$. The water vapour $\left(3 \% \mathrm{H}_{2} \mathrm{O}\right)$ was supplied to the cathode chamber by bubbling a $\mathrm{N}_{2}$ stream through a liquid water container, at $25{ }^{\circ} \mathrm{C}$. The anode was exposed to air. The voltage was applied by a Solartron 1287A electrochemical interface controlled by software CorrWare/ CorrView for automatic data collection. A constant voltage was applied and the ammonia synthesised at the cathode chamber was absorbed by $20 \mathrm{ml}$ of diluted $\mathrm{HCl}(0.001 \mathrm{M})$ for $30 \mathrm{~min}$. The concentration of $\mathrm{NH}_{4}{ }^{+}$in the absorbed solution was analysed using ISE (Thermo Scientific Orion Star A214). The rate of ammonia formation was calculated using (6):

$$
r_{\mathrm{NH}_{3}}=\frac{\left[\mathrm{NH}_{4}^{+}\right] \times V}{t \times A}
$$

where $\left[\mathrm{NH}_{4}{ }^{+}\right]$is the measured $\mathrm{NH}_{4}{ }^{+}$ion concentration, $V$ is the volume of the diluted $\mathrm{HCl}$ used for ammonia collection, $t$ is the absorption time and $A$ is the effective area of the catalyst. ${ }^{8,31}$ The faradaic efficiency for ammonia production was calculated through Faraday's law according to the produced ammonia and the recorded total charge during each measurement. ${ }^{26}$

AC impedance spectroscopy (IS) measurements were performed using a Schlumberger Solartron SI 1250 analyser, coupled with a SI 1287 Electrochemical Interface controlled by
Z-plot/Z-view software. The AC impedance spectra were recorded over the frequency range $65 \mathrm{kHz}$ to $0.01 \mathrm{~Hz}$.

\section{Results and discussion}

\subsection{XRD, SEM and thermal analysis}

The XRD patterns of LSCrF powder calcined in air at different temperatures is shown in Fig. 1. As can be seen, a single-phase perovskite oxide of LSCrF was obtained when the corresponding ash was fired at $1300{ }^{\circ} \mathrm{C}$ for $2 \mathrm{~h}$ (Fig. 2c). Below $1300^{\circ} \mathrm{C}$, a small amount of second phase $\mathrm{SrCrO}_{4}$ (JCPDS card no. 35-734) was detected. ${ }^{32}$ The crystallite size of LSCrF is about $46.75 \mathrm{~nm}$, estimated from Sherrer's formula. In order to investigate the compatibility between the CGDC and the perovskite oxide (LSCrF), the composite cathode (LSCrF-CGDC) was fired in air at $700{ }^{\circ} \mathrm{C}$ which is the sintering temperature for the single cell. As can be seen from Fig. 2, the XRD pattern of LSCrF-CGDC (Fig. 2c) displays only the corresponding peaks for CGDC (Fig. 2a) and LSCrF (Fig. 2b), no extra peaks were detected indicating that LSCrF is chemically compatible with CGDC at the single cell sintering temperature.

The SEM micrograph of the LSCrF powder calcined in air at $1300{ }^{\circ} \mathrm{C}$ for $2 \mathrm{~h}$ is shown in Fig. 3a. As can be seen, the microstructure of LSCrF powder morphology is characterised by sphere-type particles with a slight agglomeration. Fig. $3 \mathrm{~b}$ shows SEM micrograph of the cross-section view of single cell fabricated in air at $700{ }^{\circ} \mathrm{C}$ for $2 \mathrm{~h}$. The cell composes of SSCo-CGDC composite as an anode, CGDC- $(\mathrm{Li} / \mathrm{Na} / \mathrm{K})_{2} \mathrm{CO}_{3}$ as an electrolyte and LSCrF-CGDC composite as a cathode. The composite electrolyte is dense and adheres very well to the composite anode and the composite cathode, indicating good thermal compatibility.

The thermal behaviour of LSCrF cathode was investigated under $\mathrm{N}_{2}$, as the cathode is exposed to this atmosphere during the ammonia synthesis. The TGA-DSC curves of LSCrF catalyst in $\mathrm{N}_{2}$ atmosphere from room temperature up to $500{ }^{\circ} \mathrm{C}$ are shown in Fig. 4 . As can be seen, a slight $(\sim 0.26 \%)$ weight gain

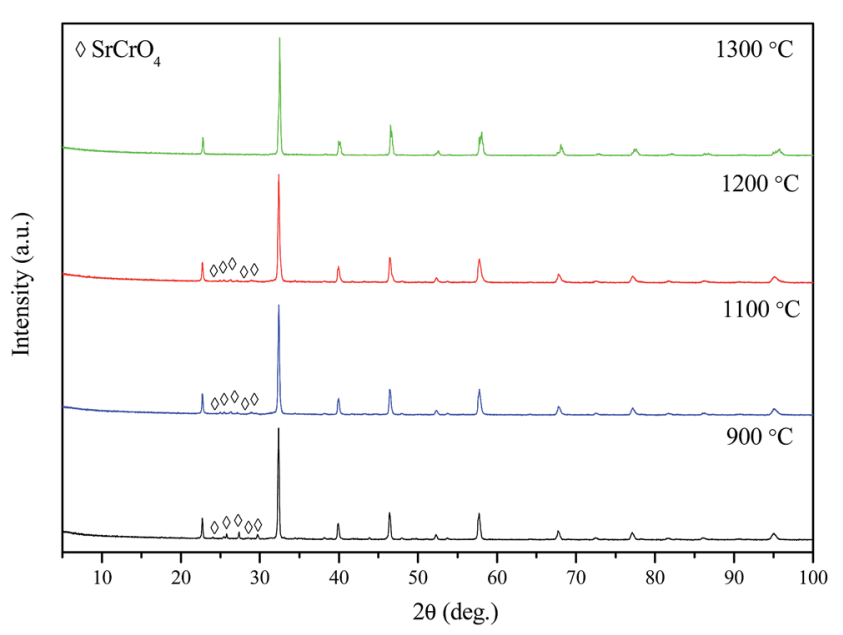

Fig. 1 XRD patterns of $\mathrm{La}_{0.75} \mathrm{Sr}_{0.25} \mathrm{Cr}_{0.5} \mathrm{Fe}_{0.5} \mathrm{O}_{3-\delta}$ at different firing conditions. 


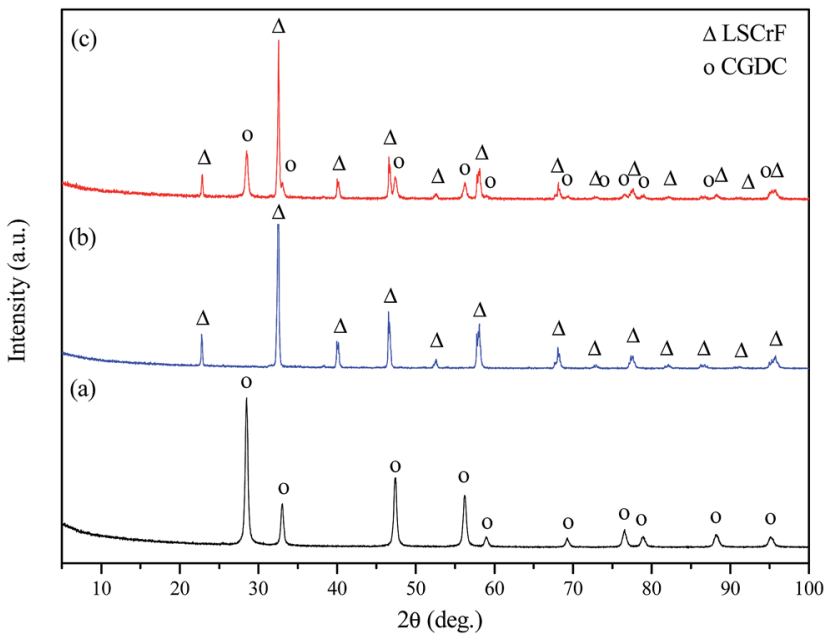

Fig. 2 XRD patterns of (a) pure CGDC; (b) pure LSCrF; (c) LSCrFCGDC composite cathode fired at $700^{\circ} \mathrm{C}$.
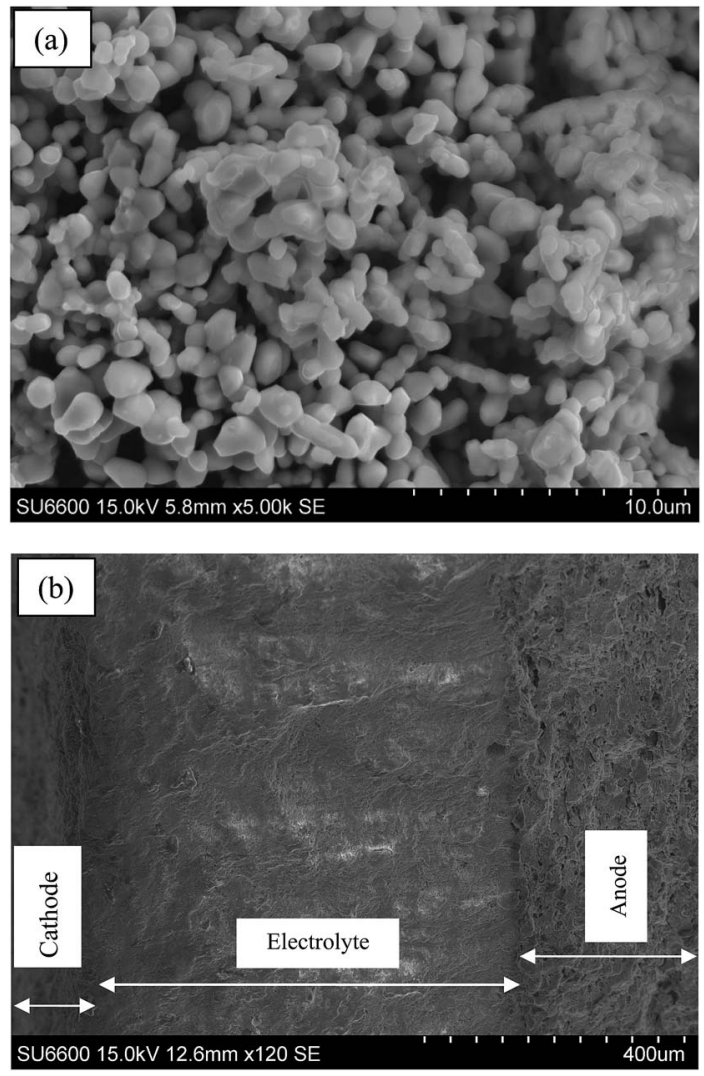

Fig. 3 SEM images; (a) LSCrF calcined in air at $1300{ }^{\circ} \mathrm{C}$ : (b) crosssectional area of the single cell before test.

was observed which is due to the buoyancy effect of air. The DSC curve shows no obvious thermal effects, indicating that there are no first order phase transitions. Sample decomposition or reaction between this perovskite-based cathode and $\mathrm{N}_{2}$ in the measured temperature range is unlikely. This suggests that LSCrF cathode is thermally stable in $\mathrm{N}_{2}$ within the measured temperature range.

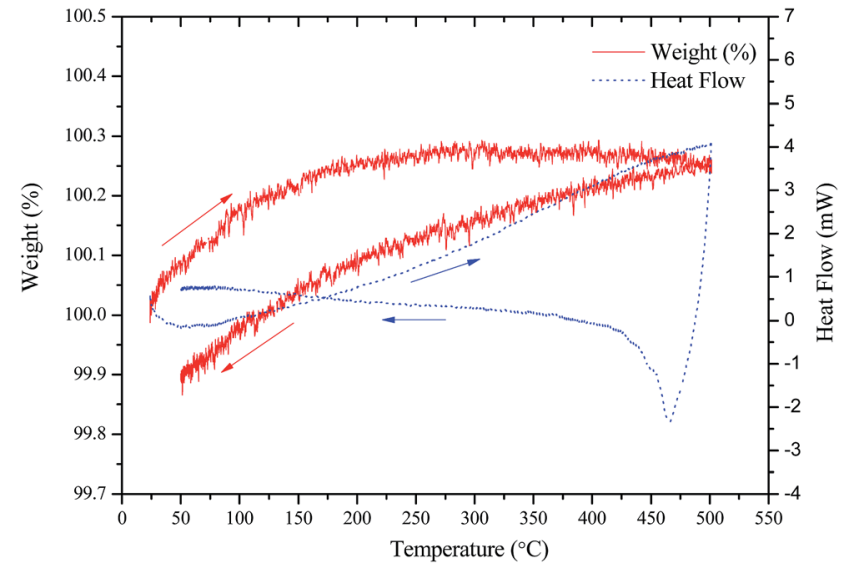

Fig. 4 TGA-DSC curves for perovskite based catalyst (LSCrF) in nitrogen, up to $500^{\circ} \mathrm{C}$.

Fig. 5 shows the performance stabilities during the ammonia synthesis at different temperatures $\left(375-425^{\circ} \mathrm{C}\right)$ with an applied voltage of $1.4 \mathrm{~V}$ over a period of $30 \mathrm{~min}$ for the electrolytic cell based on LSCrF-CGDC composite cathode. As can be seen, the performance of the cell was stable at $375{ }^{\circ} \mathrm{C}$ but the current tends to increase at higher temperatures. In addition, it is obvious that the generated current densities increase significantly as the cell operating temperature increased and reached maximum values of $23.13 \mathrm{~mA} \mathrm{~cm}{ }^{-2}$ at $425{ }^{\circ} \mathrm{C}$ for LSCrF-CGDC. This is due to the increased oxygen ions $\left(\mathrm{O}^{2-}\right)$ conductivity at evaluated temperatures.

Fig. 6a shows the in situ AC impedance spectra under open circuit conditions at different temperatures $\left(375-425{ }^{\circ} \mathrm{C}\right)$. Two depressed semicircles were observed. These data were fitted using the equivalent circuit shown in Fig. 6b. In this circuit, $L$ represents an inductance that caused by the instrument and connection wires, $R_{\mathrm{S}}$ is the series resistance $\left(R_{\mathrm{S}}\right)$ including resistances of the electrolyte, electrode materials and the contact resistance at the electrode/electrolyte interface, the two components (R1CPE1) and (R2CPE2) in series are associated to

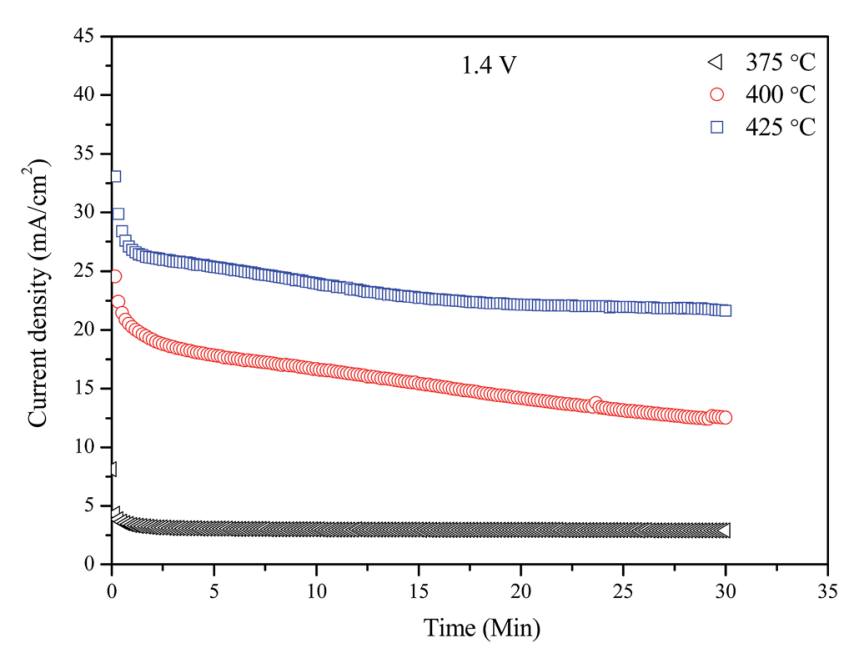

Fig. 5 Electrolytic cell performance stability at $1.4 \mathrm{~V}$ and $375-425^{\circ} \mathrm{C}$. 
(a)

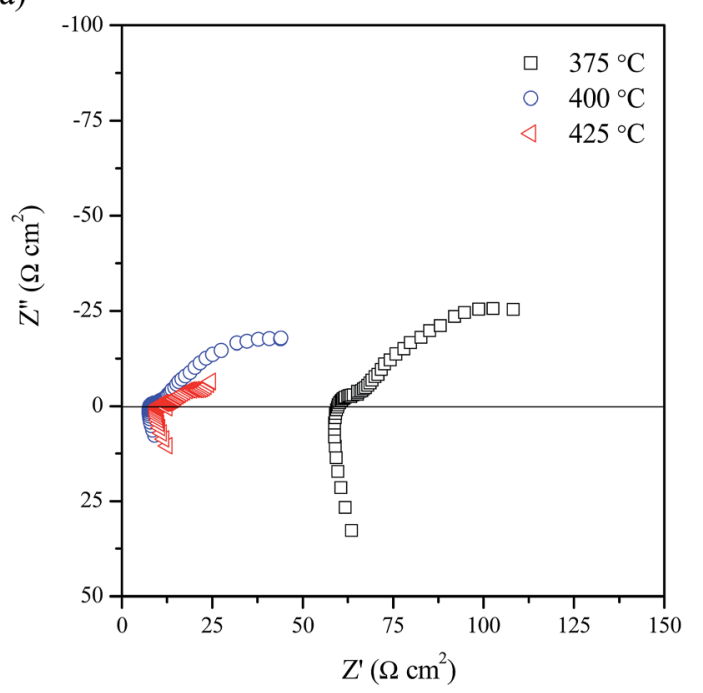

(b)

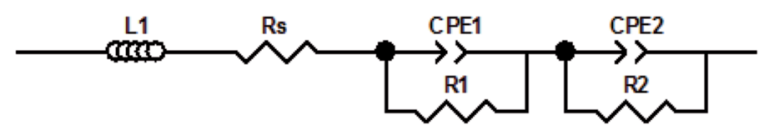

Fig. 6 Impedance spectra under open circuit condition at 375$425^{\circ} \mathrm{C}$; (b) equivalent circuit for the impedance data.

the electrode processes at high and low frequency arcs respectively. $R_{1}$ and $R_{2}$ represent the polarisation resistance while CPE is a constant phase element. It can be also seen from Fig. 6a, with increasing the cell operating temperature, the $R_{\mathrm{s}}$ which is mainly related to the ohmic resistance of the electrolyte decreased significantly due to the melting of $(\mathrm{Li}, \mathrm{Na}, \mathrm{K})_{2} \mathrm{CO}_{3}$ carbonates. In addition, the total polarisation resistance, $R_{\mathrm{p}}\left(R_{1}+R_{2}\right)$ decreased significantly with increasing the operating temperature due to enhanced catalytic activity of the electrode at evaluated temperatures.

Fig. 7 shows the effect of the operating temperature on the ammonia formation rates was investigated under constant voltage $(1.4 \mathrm{~V})$ and varying the operating temperature from 375 to $425^{\circ} \mathrm{C}$. The ammonia production rates dropped significantly as the operating temperature increased from 375 to $425{ }^{\circ} \mathrm{C}$. Furthermore, the maximum ammonia formation rate was $4.0 \times$ $10^{-10} \mathrm{~mol} \mathrm{~s}^{-1} \mathrm{~cm}^{-2}$ at $375{ }^{\circ} \mathrm{C}$ at current density of $2.99 \mathrm{~mA}$ $\mathrm{cm}^{-2}$. The corresponding Faradaic efficiency was $3.87 \% .{ }^{26}$ This low efficiency indicates that there is more than one process over the cathode surface and that the competitive hydrogen evolution reaction (HER) is the dominant one. ${ }^{33,34}$ This decrease in the ammonia formation rate with temperature, although the electrolyte ionic conductivity increases with temperature could be due the ammonia decomposition which becomes predominant at high temperature. ${ }^{35,36}$ Therefore the ammonia synthesis at higher temperature was not carried out. This experiment confirms that low temperature will benefit ammonia formation during electrochemical synthesis process. Therefore we fix the operating temperature to $375{ }^{\circ} \mathrm{C}$ in the following study.

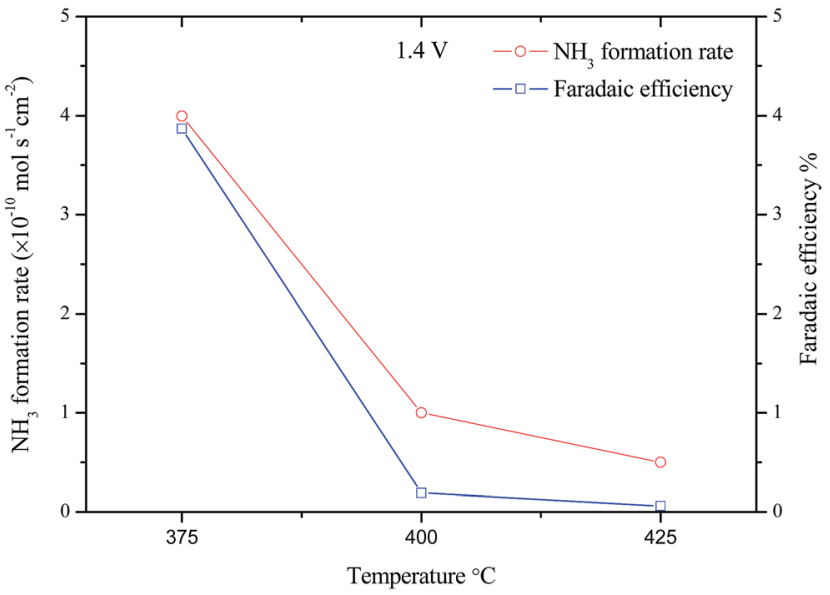

Fig. 7 Dependence of the rate of ammonia formation on the operating temperature.

\subsection{Ammonia synthesis at different applied voltages at $375{ }^{\circ} \mathrm{C}$}

Fig. 8 shows the performance stabilities of the electrolytic cell at $375^{\circ} \mathrm{C}$ and different applied voltages $(1.2-1.8 \mathrm{~V})$ over a period of $30 \mathrm{~min}$. The initial current drop is due to the blocking effects of $\mathrm{Li}^{+}, \mathrm{Na}^{+}, \mathrm{K}^{+}, \mathrm{HCO}_{3}{ }^{-}, \mathrm{CO}_{3}{ }^{2-}$ ions which has been discussed in previous studies. ${ }^{26,37,38}$ These ions may form a positively charged layer at cathode/electrolyte interface, thus partially block the transfer of the $\mathrm{O}^{2-}$ and resulting in low current densities. It should be noted that, highest current density happened at the lowest applied voltage, $1.2 \mathrm{~V}$. This means that the oxygen ion conductivity of the CGDC- $(\mathrm{Li} / \mathrm{Na} / \mathrm{K})_{2} \mathrm{CO}_{3}$ composite is related to the applied voltage. At higher applied voltage, the blocking effect of other ions are more significant leading to low $\mathrm{O}^{2-}$ ionic conductivity, thus lower current. This also indicates that the $\mathrm{O}^{2-}$ ionic conduction is not solely related to the CGDC phase, but also to the carbonates as well. Most likely, the $\mathrm{O}^{2-}$ ions are transported through the oxide-carbonate interface. ${ }^{39}$ At a higher applied voltage, the driving force for transport of $\mathrm{O}^{2-}$

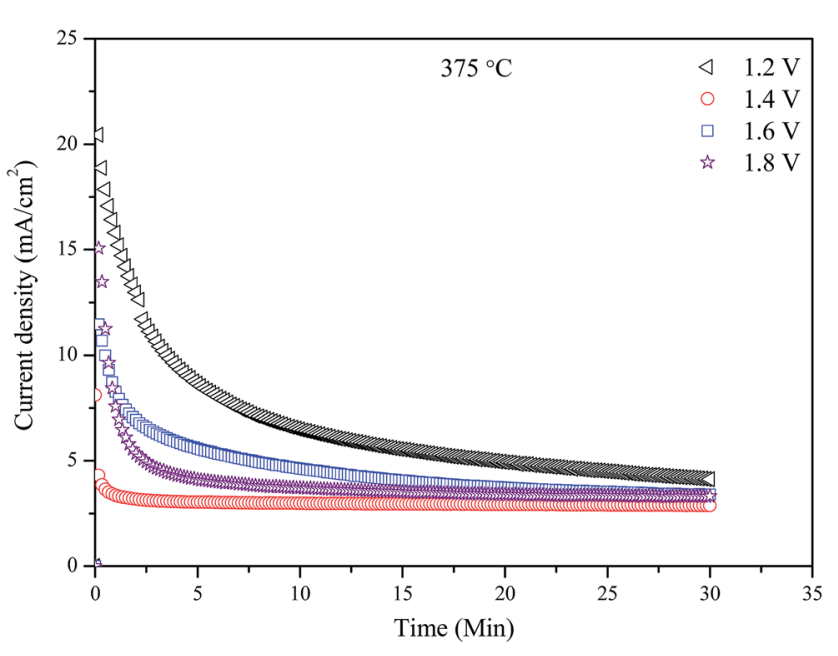

Fig. 8 Electrolytic cell performance stability at $375^{\circ} \mathrm{C}$ and $1.2-1.8 \mathrm{~V}$. 


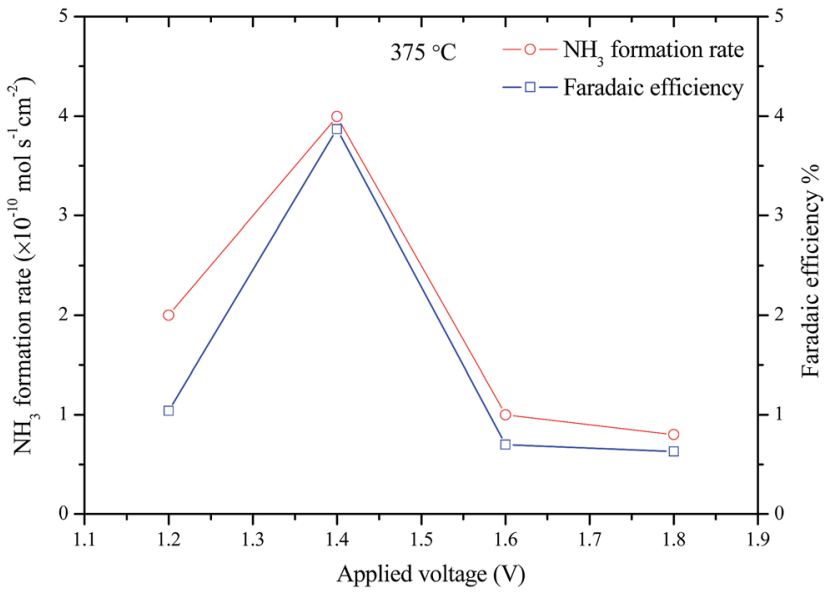

Fig. 9 Dependence of the rate of ammonia formation rate on the applied voltage at $375^{\circ} \mathrm{C}$.

ions is also higher. The two opposite effects will determine the current density. Therefore lowest current was observed at an applied voltage of $1.2 \mathrm{~V}$ (Fig. 8). The normalised final current density of the cell are $4.13,2.88,3.39$ and $3.32 \mathrm{~mA} \mathrm{~cm} \mathrm{~cm}^{-2}$ respectively. The corresponding resistances are $0.29,0.49,0.47$ and $0.54 \mathrm{k} \Omega \mathrm{cm}^{2}$ respectively. The total resistance tends to increase at higher applied voltages, indirectly confirming the blocking effect. This phenomenon was also observed in electrochemical synthesis of ammonia when a $\mathrm{H}^{+} / \mathrm{Li}^{+} / \mathrm{NH}_{4}{ }^{+}$mixed conducting membrane was used as the electrolyte. ${ }^{38}$

The ammonia formation rates and corresponding Faradaic efficiency of the cell at $375{ }^{\circ} \mathrm{C}$ with different applied voltages are shown in Fig. 9. Significant increase in ammonia formation rate was observed when applied voltage increased from 1.2 to $1.4 \mathrm{~V}$. When the electrolytic cell operated at a voltage higher than $1.4 \mathrm{~V}$, the ammonia formation rate dropped significantly which could be due to the competitive adsorption between the $\mathrm{N}_{2}$ and $\mathrm{H}_{2}$ over the cathode surface. $^{33,34}$ The maximum ammonia formation rate was $4.0 \times 10^{-10} \mathrm{~mol} \mathrm{~s}^{-1} \mathrm{~cm}^{-2}$ at $1.4 \mathrm{~V}$. An ammonia formation rate of $7.0 \times 10^{-11} \mathrm{~mol} \mathrm{~s}^{-1} \mathrm{~cm}^{-2}$ was observed for $\mathrm{Cr}$-free $\mathrm{Sr}$-doped $\mathrm{LaFeO}_{3-\delta}, \mathrm{La}_{0.6} \mathrm{Sr}_{0.4} \mathrm{FeO}_{3-\delta}$ at $1.4 \mathrm{~V}$ and $400{ }^{\circ} \mathrm{C}^{28}$ The ammonia formation rate is also higher than the $5 \times 10^{-11}$ and $1.23 \times 10^{-10}$ mol s${ }^{-1} \mathrm{~cm}^{-2}$ at $1.4 \mathrm{~V}$ and $400{ }^{\circ} \mathrm{C}$ when $\mathrm{La}_{0.6} \mathrm{Sr}_{0.4} \mathrm{Fe}_{0.8} \mathrm{Cu}_{0.2} \mathrm{O}_{3-\delta}$ and $\mathrm{La}_{0.8} \mathrm{Cs}_{0.2} \mathrm{Fe}_{0.8} \mathrm{Ni}_{0.2} \mathrm{O}_{3-\delta}$ was used as the cathode catalyst respectively for electrochemical synthesis of ammonia indicating LSCrF is potentially a better catalyst. ${ }^{26,40}$ The low ammonia production rate with the low current efficiencies $(<4 \%)$ mean that there was more than one process occurring over the cathode surface and the hydrogen evolution is the dominant one. ${ }^{\mathbf{8}, 34}$ Introduction of $\mathrm{Cr}^{3+}$ ions at the B-site in doped $\mathrm{LaFeO}_{3}$ not only improve the stability in a reducing atmosphere, but also enhance the catalytic activity for ammonia synthesis. $\mathrm{Cr}^{3+}$ ions are potential promoter for ammonia synthesis catalysts based on Fe-containing perovskite oxides.

\section{Conclusion}

$\mathrm{La}_{0.75} \mathrm{Sr}_{0.25} \mathrm{Cr}_{0.5} \mathrm{Fe}_{0.5} \mathrm{O}_{3-\delta} \quad$ (LSCrF) was synthesised via a combined EDTA-citrate complexing sol-gel process. The catalyst was characterised by X-ray diffraction (XRD), TGA-DSC analysis and scanning electron microscopy (SEM). A singlephase perovskite oxide ( $\mathrm{LSCrF}$ ) was obtained after firing the corresponding ash at $1300{ }^{\circ} \mathrm{C}$ for $2 \mathrm{~h}$. LSCrF was thermally stable in $\mathrm{N}_{2}$ atmosphere up to $500{ }^{\circ} \mathrm{C}$. A tri-layer electrolytic cell was successfully fabricated by a cost effective one-step drypressing and co-firing process. Ammonia was successfully synthesised directly from water and nitrogen $\left(3 \% \mathrm{H}_{2} \mathrm{O}-\mathrm{N}_{2}\right)$ in electrolytic cells based on cells fabricated from redox stable LSCrF-CGDC composite cathodes, CGDC-carbonate composite electrolyte and SSCo-CGDC composite anode. The maximum rate of ammonia formation was $4.0 \times 10^{-10} \mathrm{~mol} \mathrm{~s}^{-1} \mathrm{~cm}^{-2}$ with a Faradaic efficiency of $3.87 \%$ at $375{ }^{\circ} \mathrm{C}$ at an applied voltage of $1.4 \mathrm{~V}$. Compared to $\mathrm{La}_{0.8} \mathrm{Cs}_{0.2} \mathrm{Fe}_{0.8} \mathrm{Ni}_{0.2} \mathrm{O}_{3-\delta}$ catalyst, higher ammonia formation rate at reduced operating temperature was observed when $\mathrm{La}_{0.75} \mathrm{Sr}_{0.25} \mathrm{Cr}_{0.5} \mathrm{Fe}_{0.5} \mathrm{O}_{3-\delta}$ was used as the electrocatalyst. Low operating temperature will benefit ammonia formation. Introduction of $\mathrm{Cr}^{3+}$ ions at the B-site of doped $\mathrm{LaFeO}_{3}$ improves both the chemical stability and catalytic activity for ammonia synthesis.

\section{Acknowledgements}

The authors gratefully thank EPSRC SuperGen XIV 'Delivery of Sustainable Hydrogen' project (Grant no. EP/G01244X/1) for funding. One of the authors (Ibrahim A. Amar) thanks The Libyan Cultural Affairs, London for the financial support of his study in UK.

\section{References}

1 M. Appl, Ammonia: principles and industrial practice, WileyVCH, Weinheim, Germany, 1999.

2 US G. Survey, Mineral Commodity Summaries, Geological Survey, 2012.

3 E. Panagos, I. Voudouris and M. Stoukides, Chem. Eng. Sci., 1996, 51, 3175-3180.

4 G. Marnellos and M. Stoukides, Science, 1998, 282, 98-100.

5 I. A. Amar, R. Lan, C. T. G. Petit and S. W. Tao, J. Solid State Electrochem., 2011, 15, 1845-1860.

6 S. Giddey, S. P. S. Badwal and A. Kulkarni, Int. J. Hydrogen Energy, 2013, 38, 14576-14594.

7 I. Garagounis, V. Kyriakou, A. Skodra, E. Vasileiou and M. Stoukides, Front. Energy Res., 2014, 2, 1-10.

8 R. Lan, J. T. Irvine and S. W. Tao, Sci. Rep., 2013, 3, 1145.

9 R. Lan, K. A. Alkhazmi, I. A. Amar and S. W. Tao, Appl. Catal., $B, 2014$, 152-153, 212-217.

10 S. Licht, B. Cui, B. Wang, F.-F. Li, J. Lau and S. Liu, Science, 2014, 345, 637-640.

11 K. Wang, R. Ran and Z. Shao, J. Power Sources, 2007, 170, 251-258.

12 S. McIntosh and R. J. Gorte, Chem. Rev., 2004, 104, 48454866.

13 A. Skodra and M. Stoukides, Solid State Ionics, 2009, 180, 1332-1336.

14 I. A. Amar, C. T. G. Petit, G. Mann, R. Lan, P. J. Skabara and S. W. Tao, Int. J. Hydrogen Energy, 2014, 39, 4322-4330. 
15 G. Pecchi, M. Jiliberto, E. Delgado, L. Cadús and J. Fierro, J. Chem. Technol. Biotechnol., 2011, 86, 1067-1073.

16 C. Xia, W. Rauch, F. Chen and M. Liu, Solid State Ionics, 2002, 149, 11-19.

17 Z. Shao and S. M. Haile, Nature, 2004, 431, 170-173.

18 S. W. Tao and J. T. S. Irvine, Nat. Mater., 2003, 2, 320-323.

19 P. I. Cowin, C. T. Petit, R. Lan, J. T. Irvine and S. W. Tao, Adv. Energy Mater., 2011, 1, 314-332.

20 X. Yue and J. T. S. Irvine, Solid State Ionics, 2012, 225, 131135.

21 Y. Gan, J. Zhang, Y. Li, S. Li, K. Xie and J. T. Irvine, J. Electrochem. Soc., 2012, 159, F763-F767.

22 Y. Li, Y. Wang, W. Doherty, K. Xie and Y. Wu, ACS Appl. Mater. Interfaces, 2013, 5, 8553-8562.

23 W. Wang, X. Cao, W. Gao, F. Zhang, H. Wang and G. Ma, J. Membr. Sci., 2010, 360, 397-403.

24 I. A. Amar, C. T. G. Petit, L. Zhang, R. Lan, P. J. Skabara and S. W. Tao, Solid State Ionics, 2011, 201, 94-100.

25 J. Wang and R. Liu, Acta Chim. Sin., 2008, 66, 717-721.

26 R. Lan, K. A. Alkhazmi, I. A. Amar and S. W. Tao, Electrochim. Acta, 2014, 123, 582-587.

27 S. W. Tao and J. T. Irvine, Chem. Mater., 2004, 16, 4116-4121.

28 I. A. Amar, C. T. G. Petit, R. Lan, G. Mann and S. W. Tao, RSC Adv., 2014, 4, 18749-18754.
29 G. Xu, R. Liu and J. Wang, Sci. China, Ser. B: Chem., 2009, 52, 1171-1175.

30 Z. Zhang, Z. Zhong and R. Liu, J. Rare Earths, 2010, 28, 556559.

31 I. A. Amar, R. Lan, C. T. G. Petit, V. Arrighi and S. W. Tao, Solid State Ionics, 2011, 182, 133-138.

32 I. Jung, D. Lee, S. O. Lee, D. Kim, J. Kim, S. H. Hyun and J. Moon, Ceram. Interfaces, 2013, 39, 9753-9758.

33 A. Sclafani, V. Augugliaro and M. Schiavello, J. Electrochem. Soc., 1983, 130, 734-736.

34 V. Kordali, G. Kyriacou and C. Lambrou, Chem. Commun., 2000, 1673-1674.

35 C. Chen and G. Ma, J. Alloys Compd., 2009, 485, 69-72.

36 E. Perman and G. Atkinson, Proc. R. Soc. London, 1904, 74, 110-117.

37 L. Fan, G. Zhang, M. Chen, C. Wang, J. Di and B. Zhu, Int. J. Electrochem. Sci., 2012, 7, 8420-8435.

38 R. Lan and S. W. Tao, RSC Adv., 2013, 3, 18016-18021.

39 L. Fan, C. Wang, M. Chen and B. Zhu, J. Power Sources, 2013, 234, 154-174.

40 I. A. Amar, R. Lan and S. Tao, J. Electrochem. Soc., 2014, 161, H350-H354. 